\title{
The Uncertain Quality of Popular Opinion About Arkansas' Delegate Selection Format
}

\author{
GARY D. WEKKIN \\ BARTON L. SHERWOOD \\ University of Central Arkansas
}

In the 1972 Wisconsin and Michigan presidential primaries, almost 50 percent of the Republican identifiers who went to the polls cast ballots in the Democratic contests (Wekkin, 1984: 34-39). The result was that candidates who were not mainstream Democrats -- George McGovern and George Wallace--were the top two vote-getters in both contests.

One year later, the Democratic National Committee adopted a new rule different from all the other delegate selection reforms in that it actually sought to restrict, rather than encourage, participation in Democratic presidential primaries and caucuses. Rule $2 \mathrm{~A}$ required that "state parties must take all feasible steps to restrict participation in the delegate selection process to Democratic voters only" (Mikulski Commission 1973: 15). In 1978, the rule was amended to read, "participation in delegate selection shall be restricted to Democratic voters only who publicly declare their party preference and have that preference publicly recorded" (Winograd Commission 1978: 45, 70). The purpose of this rule was to force Democrats in Wisconsin, Michigan, and other "open" primary states such as Montana and Idaho to use party registration, recorded declaration of party affiliation, or some other means of preventing non-Democrats from crossing over to vote in binding Democratic presidential primaries.

However, in several of these states the open primary format and the right of crossover voting enjoyed a great deal of popular support, causing state Democrats to refuse to comply with the rule (Wekkin 1984: 50-60, 152- 54). The open-versusclosed primary dispute between the national and state parties simmered for eight years, as Wisconsin and Montana Democrats successfully defied rule $2 \mathrm{~A}$ in both 1976 and 1980. Then, the U.S. Supreme Court capped the dispute by ruling that members of the national party have a First Amendment right to limit participation in their national convention delegate selection process to sworn Democrats only, and that the Fourteenth Amendment prohibits state abridgement of this right (Democratic Party of U.S. v. La Follette, 101 S.Ct. 1010 [1981]. Consequently, Democrats in Wisconsin, Montana, and several other states used to holding open or "cross-over" (nominally closed) primaries switched to delegate selection caucuses in 1984, rather than force their voters to register by party or declare their party affiliation in writing at the polls.

One such state was Arkansas, where the caucuses held in 1984 were regarded by many as a failure. Many precinct caucuses in Little Rock were understaffed and required hours to register the unexpectedly large numbers which turned out; many caucuses in rural and small-city precincts experienced uncertain management by local regulars unfamiliar with the novel procedure; and the supporters of Gary Hart and Jesse Jackson resented the apportionment system which netted their candidates fewer delegates than was commensurate with their share of the statewide vote (Arkansas Democrat: 18 March 1984). Many elected officials and party officials issued public statements calling for a return to the presidential primary format in 1988 . Undoubtedly, presidential primary legislation would be introduced during the next legislative session. 


\section{Delegate Selection Format}

This posed several interesting and policy-relevant questions for study. Which delegate-selection and nominating system would Arkansas voters prefer, the primary or the caucuses? Given that any presidential primary law adopted would have to meet the national party's requirements ${ }^{1}$, how would voters feel about a primary that restricted participation to sworn party adherents only? What is the correlation between partisan identification and preference for open or closed nominating systems in this one-party state where Democratic primaries usually attract voters of all partisan affiliations?

\section{Methodology}

To ascertain answers to the above questions, we conducted a survey of 903 central Arkansas voters as they exited the polls on general election day, 6 November 1984. University of Central Arkansas political science majors (juniors and seniors) operating in two-person teams collected the data by interviewing every fifth voter at 31 randomly selected precincts throughout the second congressional district. 2 The interview consisted of standard NES questions concerning partisan identification, voter demographics, and candidate-preference, as well as a set of Likert items designed to produce multiple measures of attitudes concerning the primary-or-caucus and open-versus-closed primary questions. (Any questionnaire containing responsesets to the Likert items were discarded from the sample.) Although measurements of support for open or closed primary formats have been taken previously (see below), all were based on single-indicators employing a limited set of nominal responses, and are subject to the weaknesses frequently encountered with such measures (Nachmias \& Nachmias 1981: 391-92). This is the first study to attempt a more sophisticated measurement of public opinion concerning these delegate selection issues.

Our expectation was that the survey would discover that a considerable majority of the respondents prefer primaries to caucuses, inasmuch as the primary affords more accessible, less demanding, less time-consuming participation for a much greater number of people. 3 We expected to find higher than average levels of opposition to the caucus system among supporters of Jackson and Hart, the candidates who felt they had not gotten their fair share of delegates in Arkansas. However, we expected to find that most of those respondents who actually had attended a caucus should register greater support of the caucus method than those who had not attended one, and that strong partisan identifiers might support the caucus system more than weak partisans and independents.

We also expected to find that most respondents opposed changing to a closed primary format, as Blank has found true of Idaho voters (1978: 109-10) and Ranney (1975: 168) and Wekkin (1984: 52-53) each have found true of Wisconsin voters. Since until now Arkansans have not had to register by party or sign a written statement of party loyalty before voting, we presumed them to enjoy the anonymity and freedom of choice current primary eligibility requirements afford. Indeed, in a similar but smaller sample taken in 1982, Wekkin found that central Arkansans responded negatively by a margin of 63 to 25 percent to the question, "do you think that voters from one party should be barred from voting in another party's primary election?"4

Nevertheless, we hypothesized that levels of support for a closed primary should vary significantly among respondents of different partisan identification. Like the Texas Democrats who spent much of the 1970s trying to bar Republicans from their primaries (Wekkin 1984a: 55), some Arkansas Democrats should resent consistent cross-over interference enough to favor the closed format. On the other 


\section{Gary U. Wekkin and Barton L. Sherwood}

hand, Arkansas Republicans and independents should oppose any change that would bar them from the primary where most of the action is.

\section{The Findings}

The data gathered, however, matched our expectations in very few respects. While some individual indicators showed the expected distributions, others ran contrary to expectation. The various measures of support for type of delegate selection system and for type of primary format indicate considerable voter uncertainty regarding both the caucus-or-primary question and the open-versus-closed primary question. Implicit in these findings is evidence that voter knowledge about these delegate selection procedures is extremely ambiguous, as one would expect and should take into account (although we did not include items directly measuring such in order to keep the interview to a manageable length). Finally, we found very weak correlations between variables such as partisan identification or candidate preference on the one hand and support for a particular method of delegate selection on the other.

It should be noted that this central Arkansas sample appears to be representative of the statewide electorate with respect to most fixed personal attributes and acquired social attributes. For instance, 83 percent of the respondents were white, whereas census data show the population of the state to be 85 percent white; 17 percent of the respondents were over age 60, whereas census data indicate 19.3 percent of Arkansans are over $65 ; 13.2$ percent of the respondents report having completed college, compared to 11.5 percent of those in the census; and 12 percent of the respondents listed professional occupations, compared to 9 percent of those in the census. Indeed, the exit-poll respondents differ noticeably from the census profile of Arkansans only with respect to two acquired social attributes which perhaps reflect the relatively more urban and industrial character of their particular geographic region: whereas 46.5 percent of the respondents listed family incomes of over $\$ 20,000$, census data show that only 20 percent of Arkansans earn a family income of more than $\$ 25,000$ a year; and whereas only 13.2 percent of the respondents said they had not completed high school, 44.5 percent of Arkansans over the age of 25 never completed high school (U.S. Bureau of the Census 1983: 5-8ff). Consequently, the findings reported below may reflect with some accuracy the opinions one might expect to find had the population sampled been the entire state.

\section{Caucus or Primary?}

As expected, large majorities indicated a preference for the presidential primary over the caucus system of delegate selection used by Arkansas Democrats in 1984. About 71 percent agreed and only 12 percent disagreed with the statement that "primaries are a more democratic way to nominate candidates than caucuses"; and 79 percent agreed while 10 percent disagreed with the statement that "the best way to nominate party candidates is to let the people vote in a primary." About 62 percent disagreed while only 17 percent agreed with a statement that caucuses produce better candidates than primaries do (see Table 1 at the end of paper).

It should be noted, however, that many of the respondents lacked the information necessary to compare the two systems. Only 8 percent of the respondents had attended the 1984 caucuses of either party, and could speak from personal familiarity with the system. Indeed, ignorance of what happens in a caucus may 


\section{Delegate Selection Format}

account partially for the overwhelming preference for primaries registered by items in which only labels, not substantive descriptions, are present.

Levels of support for primaries and caucuses, respectively, altered considerably when the two systems were contrasted in descriptive terms only, without lavels and the associations they carry. The margin preferring primaries to caucuses shrank by 40 percent when respondents were asked to agree or disagree with the proposition that having people gather to discuss the candidates before voting would be a better way to pick presidential candidates than letting people simply vote and leave (Table 1). In fact, several items revealed that many who prefer the primary system nevertheless recognize that the caucuses offer certain advantages over the primaries. For instance, 65 percent of the respondents agreed that "those who take the time to attend party delegate selection caucuses are usually better informed than the average primary voter," and a slight plurality (39 to 33 percent) agreed that "the caucus meetings could be a good way to get more people directly involved in our government."

The bottom line is that the Likert index for all of the items comparing primaries to caucuses in Table 1 is 2.34 , which indicates a tendency closer to "agreement" (that primaries are better) than to "mixed feelings." Central Arkansans register a clear, but not "strong", preference for the primary system of delegate selection.

As we had expected, Democrats proved stronger supporters of the party caucuses than other respondents, but by a slighter margin that expected. Democrats registered a Likert score of 2.49 over the items in Table 1, com pared to a Likert score of 2.44 for Republicans and 2.33 for independents. This margin widened somewhat when partisanship was controlled for strength of party identification. Strong Democrats registered a Likert score of 2.52 over the above items, compared to only 2.34 for strong Republicans, who appear to prefer presidential primaries to their own caucus system of delegate selection somewhat more than do weak Republicans (Likert-2.58). Perhaps this may be read as evidence of mischievous intent on the part of some strong Republicans.

Also as expected, respondents who had attended the caucuses proved somewhat more supportive of the caucuses than those who had not attended. The Likert index for caucus participants' responses to all of the items in Table 1 is almost 3.0. However, cross-tabulation and contingency coefficients for each individual item indicate at best a weak association between attendance and support for caucuses, and the $\mathrm{N}$ of those attending is so small (76) that even a strong association would be inconclusive at best.

Indeed, the small $\mathrm{N}$ of those attending the caucuses rendered meaning less any attempt to confirm the hypothesis that Jackson and Hart supporters should register higher than average levels of opposition to the caucus system. However, we did cross-tabulate attitudes toward the caucus system by race to see if such an analysis might suggest dissatisfaction with the caucuses among Jackson supporters, and were surprised to find that blacks registered support for caucuses comparable to that of caucus participants, and scored about 0.4 closer to "mixed feelings" (a relativelymore positive evaluation) than did whites.

\section{Open or Closed Primary?}

Our findings concerning the open-versus-closed primary issue contained several surprises. The biggest, of course, was the turnaround in opinion on this question in central Arkansas since 1982. At that time, 63 percent of the respondents answered "no" and 26 percent answered "yes" when asked if voters from one party "should be barred" from the other party's primary. In 1984, however, 58 percent of the 


\section{Gary D. Wekkin and Barton L. Sherwood}

respondents agreed and only 28 percent disagreed with the statement, "it is unfair to let supporters of one party help pick the other party's candidates" (see Table 2). Two factors may have contributed to the different finding. One is that Likert items offer a wider range of responses (and thus are presumably more accurate) than the "yes or no" option available to 1982 respondents. The other is that the 1984 Likert item only asks respondents what they think is fair, and does not ask them to approve restrictive measures, as the 1982 survey-item does. Note that when the 1984 respondents were read the statement, "voters should have to declare their loyalty to a party in order to help pick the party's candidates for office," the percentage of those who agreed dropped to 44 percent while those who disagreed rose to 42 per cent (Table 2). The respondents were even less willing (in fact, a plurality were opposed) to require independents to declare loyalty to a party in order to vote in its primary. It appears that those who at first agreed that cross-over voting was unfair may not have been familiar with or had not thought about the disfranchisement that "fairness" would entail; or that Arkansans may not like prohibitions and may not wish to regulate every practice that is recognized as unfair.

Nonetheless, even the latter two items in Table 2 show considerably more support for a closed primary than the 1982 question did. The Likert index for all three items is 2.91 , which is much closer to "mixed feelings" than "agree" but indicates a slight preference among central Arkansans for the closed primary format.

Contrary to what we expected, Democrats, whose control over their own presidential nomination and delegate-selection process is in question, ap peared little more inclined than other respondents to prefer a closed primary format (See Tables 3 and 4). Indeed, the Chi Square level of significance for Table 3 indicates a 55 percent probability that such a frequency distribution could result from chance. By controlling for strength of partisan attachment, we discovered that strong Democrats and strong Republicans do register somewhat stronger differences with each other over the three open-versus-closed primary items in Table 2. Strong Democrats register a Likert score of 2.45 for these combined items, compared to a Likert score of 2.82 for strong Republicans. Weak Democrats and weak Republicans cancelled this mild divergence by registering an amazingly similar distribution of responses on these items (two of these distributions are shown in Tables 5 and 6).

\section{Conclusion}

It is unwise to measure popular attitudes on the basis of one or two simple indicators. Where certain individual items indicated overwhelming support for primaries over caucuses and solid support for closed over open primaries, other measures used yielded significantly different findings. Moreover, this uncertainty of opinion spans all partisan and racial categories--no significant relationship exists between partisan identification, race, or any other demographic variable (age, gender, education, occupation, income) and one's opinions concerning delegate selection format. This suggests that public opinion remains very malleable with respect to delegate selection methods.

Those elected officials and party leaders who recently enacted legislation mandating the selection of national convention delegates through an open presidential primary in 1988 perhaps should reconsider that hasty action. There really is not as much anti-caucus sentiment among the public as some have assumed there is. Perhaps with more voter education and better organization of the caucuses, the system might perform better a second time. In any case, the soft, pliable state of 


\section{Delegate Selection Format}

current opinion of these questions affords Arkansas Democratic leaders considerable latitude to do as they wish without much fear of public reprisal. Neither the caucus nor a closed primary would spark as much controversy in Arkansas as has occurred in the open primary states of the upper midwest.

On the other hand, the somewhat mystifying results of this central Arkansas sample implicitly convey the extent of which the partisan beliefs and electoral behavior of Arkansans and of voters in other border and southern states have begun to resemble certain classical democratic beliefs (e.g., open parties and elections, mass individual participation) that are characteristic of what Elazar terms the "moralistic" political culture of our northern tier of states (1972: 10-30). Savage and his associates $(1977 ; 1984)$ already have suggested that Arkansans inhabiting the northwestern Ozarks region contiguous to Oklahoma and Missouri subscribe to a number of participatory values and policy preferences consonant with the "moralistic" cultural stream. According to our data, central Arkansans' value preferences concerning the presidential-nomination and delegate-selection processes seem to sprawl between the open, participatory values of the northern tier and the more restrictive, differential, complacent ideals of the "traditionalistic" political culture of the southern rim. Even the strong partisans interviewed in this study were only slightly less inclined than other respondents to regard the nomination and delegate-selection functions as rightfully the domain of the voting masses, rather than of enrolled party members and self-designated adherents. In appears that regardless of their different regional, ethnic, and socioeconomic backgrounds, most Americans today think of democracy as a procedure, not as a condition or result. Government by the people is preferred to government for the people, and participation is valued more than the viability of in stitutions and the choices they make, even in a nominally "traditionalistic" southern state such as Arkansas.

\section{Notes}

1. Contrary to some recent reports, Rule $2 \mathrm{~A}$ has not been dropped for 1988 . The Fairness Commission incorporated an exemption for Wisconsin Democrats in 1988 Rule 2A, but Arkansas and other states continue to be bound by the rule for the present.

2. All data were encoded personally by the project director/senior author.

3. Just prior to the 1984 caucuses, editor Robert McCord of the Arkansas Gazette opined that "independent-minded Arkansans" would never embrace a system which required them to sign declarations of loyalty to the Democratic party and cast their votes before a public gathering (Westmoreland 1985: 12).

4. Data are available from the senior author.

\section{References}

Blank, Robert H. (1978). Regional Diversity of Political Value. Washington, D.C.: University Press of America.

Elazar, Daniel J. (1972). American Federalism. New York: Thomas Y. Crowell.

Mikulski Commission on Delegate Selection and Party Structure (1973). Democrats All. Washington, D.C.: Democratic National Committee. 


\section{Gary D. Wekkin and Barton L. Sherwood}

Nachmias, David and Chava Nachmias (1981). Research Methods in the Social Sciences. New York: St. Martin's Press.

Ranney, Austin (1975). Curing the Mischiefs of Faction. Berkeley, Cal.: University of California Press.

Savage, Robert L. and R.J. Gallagher (1977). "Politocultural Regions in a Southern State: An Empirical Typology of Arkansas Counties." Publius 7: 91-105.

Savage, Robert L. and Diane D. Blair (1984). "Regionalism and Political Opinion in Arkansas: An Exploratory Survey." Arkansas Political Science Journal 5: 59-85.

U.S. Bureau of the Census (1983). Congressional Districts of the 98th Congress. Washington, D.C.: U.S. Government Printing Office.

Wekkin, Gary D. (1984). Democrat versus Democrat: The National Party's Campaign to Close the Wisconsin Primary. Columbia, Mo.: University of Missouri Press.

. (1984a). "National-State Party Relations: The Democrats' New Federal Structure." Political Science Quarterly 99: 45-72.

Westmoreland, Andrew. "The Caucus Experiment in Arkansas Democratic Party Politics." Paper delivered at 1985 meeting of the Arkansas Political Science Association, Russellville, Ark., 23 February 1985.

Winograd Commission on Presidential Nomination and Party Structure (1978). Openness, Participation, and Party-Building. Washington, D.C.: Democratic National Committee. 
Gary D. Wekkin and Barton L. Sherwood

Table 1.

Central Arkansans' Preferred Method of Delegate Selection*

Statement

12

Strongly Mixed Strongly

Agree Agree Feelings Disagree Disagree Total

"The best way to nominate

party candidates is to let

the people vote in a

primary."

14.9

$64.2-10.6$

9.5

0.8

100

"Primaries are a more democratic way to nominate candidates than caucuses."

$\begin{array}{llll}16.5 & 54.6 & 16.5 & 10.5\end{array}$

1.8

100

"Caucuses are a more reliable way to nominate good candidates than primaries."

$\begin{array}{llll}3.5 & 13.5 & 21.2 & 50.2\end{array}$

11.7

100

"Having people gather together to discuss the various candidates before voting would be a better way to pick presidential candidates than letting people simply sign in, vote, and leave."

$\begin{array}{llll}4.0 & 26.8 & 19.4 & 42.3\end{array}$

7.5

100

${ }^{*}$ The $\mathrm{N}$ for the four items in this table ranged between 893 and 898 .

Likert Index for Table 1: 2.34

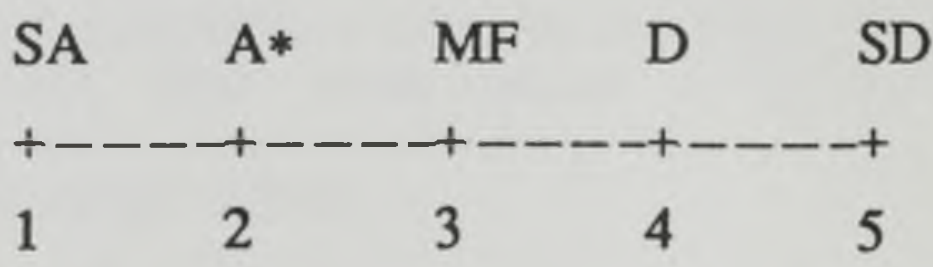


Table 2.

Support for Closed Primaries Among Central Arkansans*

\begin{tabular}{|c|c|c|c|c|c|c|}
\hline & 1 & 2 & 3 & 4 & 5 & \\
\hline Statement & $\begin{array}{l}\text { Strongly } \\
\text { Agree }\end{array}$ & Agree & $\begin{array}{l}\text { Mixed } \\
\text { Feelings }\end{array}$ & Disagree & $\begin{array}{c}\text { Strongly } \\
\text { Disagree }\end{array}$ & Total \\
\hline
\end{tabular}

"It is unfair to let

supporters of one party

help pick the other party's

candidates."

$\begin{array}{llll}14.4 & 43.5 & 14.1 & 23.2\end{array}$

4.8

100

"Voters should have to declare

their loyalty to a party in

order to help pick that party's

candidates for office."

$\begin{array}{lllll}16.5 & 54.6 & 16.5 & 10.5 & 1.8\end{array}$

100

"Independent voters who won't

declare loyalty to a party

should not be allowed to help

pick its candidates for

office."

$\begin{array}{llll}6.1 & 28.2 & 20.2 & 36.8\end{array}$

8.8

100

${ }^{*}$ The $\mathrm{N}$ for the four items in this table ranged between 901 and 903.

Likert Index for Table 2: 2.91

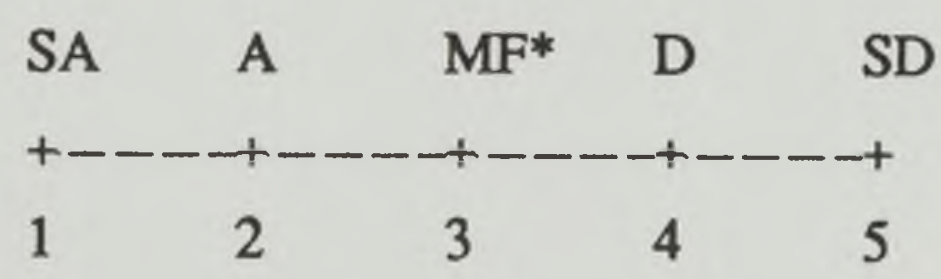


Gary D. Wekkin and Barton L. Sherwood

Table 3.

Partisan Identification and Perception That Crossover Voting is Unfair

"It is unfair to let supporters of one party help pick the other party's candidates."

Response

Republican

Strongly Agree

Agree

Mixed Feelings

Disagree

Strongly Disagree

$\mathrm{N}$ of Respondents
18.9

14.3

37.9

16.6

20.7

5.9

169

412

272 
Table 4.

Partisan Identification and Willingness to Bar Non-Identifiers

Voters should have to declare their loyalty to a party in order to help pick that party's candidates for office."

\begin{tabular}{rrrrr} 
Response & \multicolumn{5}{c}{ Partisan Identification } \\
& Republican & Democrat & Independent & Other \\
Strongly Agree & 14.7 & 12.1 & 4.4 & 9.5 \\
Agree & 30.6 & 39.2 & 29.4 & 9.5 \\
Mixed Feelings & 12.4 & 13.8 & 14.7 & 14.3 \\
Disagree & 31.8 & 29.8 & 39.3 & 47.6 \\
Strongly Disagree & 10.6 & 5.1 & 12.1 & 19.0 \\
& & & & 21
\end{tabular}


Table 5.

Intensity of Partisan Identification and Perception that Crossover Voting is Unfair

"It is unfair to let supporters of one party help pick the other party's candidates."

Response

Partisan Identification

\begin{tabular}{rcccc}
\hline & $\begin{array}{c}\text { Strong } \\
\text { Republican }\end{array}$ & $\begin{array}{c}\text { Weak } \\
\text { Republican }\end{array}$ & $\begin{array}{c}\text { Weak } \\
\text { Democrat }\end{array}$ & $\begin{array}{c}\text { Strong } \\
\text { Democrat }\end{array}$ \\
Strongly Agree & 24.5 & 11.9 & 10.1 & 20.3 \\
Agree & 36.2 & 45.8 & 42.2 & 49.7 \\
Mixed Feelings & 12.8 & 15.3 & 18.6 & 7.0 \\
Disagree & 20.2 & 22.0 & 25.1 & 19.8 \\
Strongly Disagree & 6.4 & 5.1 & 4.0 & 3.2 \\
\hline N of Respondents & 94 & 59 & 199 & 187
\end{tabular}




\section{Delegate Selection Format}

Table 6.

Intensity of Partisan Identification and Willingness to Bar Non-Identifiers

"Voters should have to declare their loyalty to a party in order to help pick that party's candidates for office."

Response Partisan Identification

$\begin{array}{cccc}\text { Strong } & \text { Weak } & \text { Weak } & \text { Strong } \\ \text { Republican } & \text { Republican } & \text { Democrat } & \text { Democrat }\end{array}$

$\begin{array}{rrrrr}\text { Strongly Agree } & 18.9 & 11.9 & 6.0 & 20.2 \\ \text { Agree } & 27.4 & 33.9 & 32.2 & 47.9 \\ \text { Mixed Feelings } & 9.5 & 11.9 & 14.6 & 10.6 \\ \text { Disagree } & 31.6 & 32.2 & 39.7 & 19.1 \\ \text { Strongly Disagree } & 12.6 & 10.2 & 7.5 & 2.1\end{array}$

$\mathrm{N}$ of Respondents

95

59

199

188 